\title{
RETURN PASAR MODAL DAN PASAR RAKYAT?
}

\author{
M. ALI FIKRI \\ Jurusan Akuntansi Fakultas Ekonomi dan Bisnis Universitas Mataram \\ fikri.sampala@unram.ac.id \\ SAIPUL ARNI MUHSYAF \\ Jurusan Akuntansi Fakultas Ekonomi dan Bisnis Universitas Mataram \\ saipulam@unram.ac.id \\ NUNGKI KARTIKASARI \\ Jurusan Akuntansi Fakultas Ekonomi dan Bisnis Universitas Mataram \\ nungkikartikasari@unram.ac.id
}

\author{
Article History: \\ Received: 20 Januari 2021 \\ Revised: 3 September 2021 \\ Accepted: 3 September 2021 \\ DOI: $10.29303 /$ jaa.v6i1.98
}

\begin{abstract}
The value relevance according to Beaver (1968) is the explanatory power of accounting information, for example accounting earnings and book value are related to firm value represented by stock prices. The phenomenon is that many players from the capital market are carried out by the middle to upper class, even though on the other hand there are small investments that also generate returns, for example the traditional market. This study examines the differences in the value relevance of the capital market and the traditional market to obtain empirical evidence about the relevance of the value of stock returns between the capital market and the traditional market. This research was conducted around the scope of the Indonesian Capital Market (IDX) and Traditional Markets in the Mataram area. The results showed that the value of traditional market returns was more profitable than the capital market.
\end{abstract}

Abstrak: Relevansi nilai menurut Beaver (1968) merupakan explanatory power dari informasi akuntansi, misalnya laba akuntansi dan nilai buku hubungannya dengan nilai perusahaan yang direpresentasikan dengan harga saham. Fenomenanya, banyak pemain dari pasar saham dilakukan oleh kalangan menengah ke atas, padahal di lain sisi terdapat investasi kecil yang juga menghasilkan return, misalnya pasar rakyat. Penelitian ini menguji perbedaan relevansi nilai pasar saham dan pasar rakyat untuk memperoleh bukti empiris tentang relevansi nilai return saham antara pasar modal dan pasar rakyat. Penelitian ini dilakukan di sekitar ruang 


\section{$\partial A A$}

Vol. 6, No. 1, Oktober 2021

lingkup Pasar Modal Indonesia dan Pasar Tradisional di daerah Mataram. Hasil penelitian menunjukkan nilai Return Pasar rakyat lebih menguntungkan dibandingkan dengan Pasar Modal.

Keyword : return, traditional market, capital market.

Kata kunci : return, pasar modal, pasar rakyat

\section{PENDAHULUAN}

Relevansi nilai merupakan salah satu area yang memberikan kontribusi besar dalam riset akuntansi berbasis pasar modal (Beaver 2002). Riset relevansi nilai berawal dari riset empiris akuntansi yang dilakukan Ball dan Brown tahun 1968 (Francis dan Schipper, 1999) melalui pengujian usefulness informasi laba akuntansi yang mempengaruhi rata-rata abnormal return pasar. Relevansi nilai dipahami sebagai kemampuan penjelas informasi angka akuntansi, terutama laba dan nilai buku terhadap harga sekuritas. Apakah angka akuntansi memiliki nilai yang bermanfaat bagi investor, dan lebih ditekankan lagi, apakah angka akuntansi memang merupakan nilai yang relevan menjelaskan harga saham di pasar sekuritas.

Riset relevansi nilai secara spesifik melakukan pengujian argumentasi melalui prediksi asosiasi antara variabel dependen yang berbasis harga sekuritas dan variabel independen informasi akuntansi. Angka akuntansi dianggap memiliki nilai relevan bila secara signifikan berhubungan dengan variabel dependen. Riset relevansi nilai didasarkan pada dua kombinasi basis teoritis, yaitu valuation theory dan argumen kontekstual akuntansi tentang bagaimana variabel akuntansi berhubungan dengan nilai pasar ekuitas (Beaver, 2002). Riset relevansi nilai mengombinasikan pendekatan nilai buku dan laba akuntansi.

Riset relevansi nilai (misalnya, Jones, 1991; Ohlson, 1995; Dechow et al., 1995; Burgstahler dan Dichev, 1997; Francis dan Schipper, 1999; Barth et al., 1999; Marquardt dan Wiedman 2004) menyatakan relevansi nilai bergantung dari kualitas informasi yang tersedia. Ketersediaan informasi yang disajikan akan direspon investor untuk menilai kinerja perusahaan (Subramanyam, 1996; Beaver, 2002). Permasalahan yang berhubungan dengan relevansi nilai, yaitu apakah kualitas informasi yang disajikan sesuai kondisi perusahaan sesungguhnya.

Kualitas informasi berhubungan dengan perilaku penyusun laporan, yaitu pihak manajemen karena laporan keuangan merupakan bentuk tanggung jawab manajemen atas sumber daya pemilik. Akses informasi internal dan prospek perusahaan di masa mendatang yang dimiliki lebih banyak oleh manajemen dibandingkan investor dapat menimbulkan 
asimetri informasi. Kondisi ini dapat mendorong pihak manajemen berperilaku opportunistic dan memilih kebijakan akuntansi sesuai dengan kepentingannya, di samping standar akuntansi memberikan fleksibilitas untuk memilih seperangkat kebijakan jika kinerja manajemen diukur berdasarkan laba (Healy, 1985). Perilaku disfunctional behaviour ini disebut sebagai perilaku manajemen laba (earning management).

Konsekuensi perilaku manajemen laba ini, yaitu laporan keuangan tidak lagi mencerminkan kondisi sesungguhnya dan menyebabkan investor tidak bisa menyandarkan diri sepenuhnya pada informasi yang disajikan untuk mengukur kinerja perusahaan (Marquardt dan Wiedman, 2004). Untuk menjamin ketersediaan informasi yang lebih baik, pihak investor berusaha mencari metode alternatif lain mengukur kinerja perusahaan.

Relevansi nilai menurut Beaver (1968) merupakan explanatory power dari informasi akuntansi, misalnya laba akuntansi dan nilai buku hubungannya dengan nilai perusahaan yang direpresentasikan dengan harga saham. Angka akuntansi dianggap sebagai nilai yang relevan bila secara signifikan berhubungan dengan variabel dependen dan informasi laba rugi dan neraca merupakan bentuk relevansi nilai yang tercermin dalam return saham.

Dilihat dari fenomena saat ini di Indonesia, kenyataannya banyak pemain dari pasar saham dilakukan oleh kalangan menengah ke atas, sehingga penelitian ini mencoba melakukan perbandingan antara return di pasar modal dengan return di pasar rakyat, dengan asumsi bahwa keduanya sama sama memiliki daya penjelas yang baik, apakah return yang dihasilkan ketika berinvestasi di pasar saham dengan pasar rakyat berbeda, dan mana yang lebih tinggi di antara keduanya.

\section{TELAAH LITERATUR DAN PENGEMBANGAN HIPOTESIS}

\section{Pasar Rakyat}

Sesuai dengan Peraturan Menteri Perdagangan RI Nomor: 56/M_DAG/PER/9/2014 tentang Perubahan atas Peraturan Menteri Perdagangan Nomor 70/M-DAG/PER/12/2013 Tentang Pedomanan Penataan dan Pembinaan Pasar Tradisional, Pusat Perbelanjaan dan Toko Modern. Pada Pasal II ayat 1 bahwa penyebutan Pasar Tradisional itu sekarang menjadi Pasar Rakyat.

Pasar Rakyat adalah pasar yang pelaksanaannya bersifat tradisional tempat bertemunya penjual pembeli, terjadinya kesepakatan harga dan terjadinya transaksi setelah melalui proses tawar-menawar harga. Biasanya pasar Rakyat umumnya menyediakan berbagai macam bahan pokok keperluan rumah tangga, dan pasar ini biasanya berlokasi di tempat yang terbuka. 


\section{$D A A$}

Vol. 6, No. 1, Oktober 2021

\section{Pasar Modal}

Pengertian Pasar Modal adalah suatu pasar yang beroperasi secara terorganisir dimana terdapat aktivitas perdagangan surat-surat berharga seperti saham, equitas, surat pengakuan hutang, obligasi, dan surat berharga lainnya yang diterbitkan oleh pemerintah maupun perusahaan swasta dengan memanfaatkan jasa perantara, komisioner, dan underwriter. Menurut UU No. 8 Tahun 1995, arti pasar modal adalah suatu aktivitas yang berhubungan dengan perdagangan efek dan penawaran umum, perusahaan publik yang berhubungan dengan efek yang diterbitkannya, serta lembaga dan profesi yang berhubungan dengan efek. Dengan kata lain, pasar modal adalah penghubung antara investor (pemilik dana) dengan perusahaan atau institusi pemerintah yang membutuhkan dana melalui perdagangan instrumen jangka panjang (saham, obligasi, right issue, dan lain-lain).

\section{Return dan Resiko}

Investasi dapat diartikan sebagai komitmen untuk menanamkan sejumlah dana pada saat ini dengan tujuan memperoleh keuntungan di masa datang. Dengan kata lain, investasi merupakan komitmen untuk mengorbankan konsumsi sekarang dengan tujuan memperbesar konsumsi di masa datang. Pengertian lain investasi adalah suatu bentuk penanaman dana atau modal untuk menghasilkan kekayaan, yang akan dapat memberikan keuntungan tingkat pengembalian (return) baik pada masa sekarang atau dan di masa depan.

Investasi dapat berkaitan dengan penanaman sejumlah dana pada aset riil (real assets) seperti: tanah, emas, rumah, barang-barang seni, real estate dan aset riil lainnya atau pada aset finansial (financial assets), berupa surat-surat berharga yang pada dasarnya merupakan klaim atas aktiva riil yang dikuasai oleh entitas seperti: deposito, saham, obligasi, dan surat berharga lainnya. Harapan keuntungan di masa datang merupakan kompensasi atas waktu dan risiko yang terkait dengan investasi yang dilakukan. Dalam konteks investasi, harapan keuntungan tersebut sering disebut sebagai return.

\section{Return dan Resiko Pasar Rakyat vs Return Pasar Modal}

Sebagaimana telah dijelasakan di atas, hubungan antara return dan resiko sangat kuat, namun terlepas dari hal tersebut yang penting diperhatikan adalah mengenai return realisasi, bukan return berbentuk accrual. Beberapa penelitian terdahulu menyatakan terjadinya penurunan relevansi return saham ${ }^{1}$ di pasar modal yang berhubungan dengan

\footnotetext{
${ }^{1}$ Relevansi nilai didefinisikan sebagai hubungan antara informasi akuntansi dan nilai pasar saham (Francis dan Shipper, 1999; Barth, Beaver, dan Landsman, 2001). Pengukur relevansi nilai adalah
} 
akuntansi, sebagaimana dinyatakan oleh beberapa hasil penelitian, yaitu: Sloan (1996) menyatakan pada awalnya nilai pasar saham perusahaan yang melakukan kebijakan akuntansi akrual akan meningkat dan kemudian menurun pada tahun berikutnya karena pergeseran laba tahun ke depan ke periode sekarang. Kenaikan nilai saham perusahaan yang melakukan manajemen laba pada saat dilakukannya penawaran saham hanya bersifat sementara dan akan menurun pada periode berikutnya seiring dengan menurunnya laba.

Brugstahler dan Dichev, (1997) melakukan uji model penilaian earnings dan nilai buku terhadap nilai pasar perusahaan menggunakan data penelitian dari tahun 1976-1994. Penelitiannya menggunakan variabel market value (MV), book value (BV), dan earnings (E), serta menggunakan varaibel perubahan MV, BV, dan E secara cross section dan pooled. Hasil penelitiannya menggunakan cross section dan pooled menemukan nilai variabel earnings yang siginfikan untuk seluruh regresi sampel, sesuai dengan teori relevansi nilai atas earnings dan menemukan penurunan nilai $\mathrm{R}^{2}$ dari tahun 1976 sampai dengan tahun 1994.

Rangan (1998) meneliti perusahaan yang melakukan penawaran saham pada menggunakan sampel sebanyak 230 perusahaan tahun 19871990. Hasil penelitiannya menemukan pada saat saham ditawarkan, terjadi peningkatan abnormal stock return berasarkan laba dan akan menurun pasca pengumuman. Penurunan ini disebabkan karena perusahaan melakukan transitory increases in earnings selama periode penawaran saham. Pada periode berikutnya, harga saham perusahaan akan menurun karena perusahaan melaporkan laba yang rendah. Ditemukan juga discretionary accrual selama periode penawaran berhubungan negatif dengan perubahan laba tahun berikutnya dan menyimpulkan pasar saham tidak mengetahui discretionary accrual yang dilakukan perusahaan.

Francis dan Schipper (1999) menguji relevansi nilai informasi akuntansi selama periode 1952-1994 dan menemukan relevansi nilai return berdasarkan earnings mengalami penurunan. Hasil pengujian relevansi nilai return berdasarkan nilai buku aset dan liabilities baik secara parsial yang dikombinasikan dengan earnings tidak mengalami penurunan. Francis dan

\footnotetext{
kekuatan penjelas secara menyeluruh dari informasi akuntansi terhadap harga saham (Marqardt dan Wiedman, 2004) yang diukur menggunakan nilai $R^{2}$. Brown, et al. (1999) menyatakan penelitian biasanya melakukan regresi stock prices on earnings per share untuk mengestimasi relevansi nilai informasi akuntansi yang akan menghasilkan $\mathrm{R}^{2}$ yang memiliki nilai mendekati nol. Nilai $R^{2}$ ini selanjutnya digunakan untuk mengukur relevansi nilai. Jika terjadi peningkatan nilai $R^{2}$ secara terus menerus berarti terjadi peningkatan relevansi nilai dan sebaliknya. Metoda pengukuran lain relevansi nilai adalah nilai koefisien dari variabel akuntansi yang dianalisis (Marqardt dan Wiedman, 2004). Peningkatan riset relevansi nilai yang signifikan, disebut Beaver (2002) telah mendominasi era riset tahun 1990-an terutama berkaitan dengan variabel dependen berbasis harga sekuritas maupun volume perdagangan hubungannya dengan set dari variabelvariabel akuntansi maupun non-akuntansi
} 


\section{DA}

Vol. 6, No. 1, Oktober 2021

Schipper (1999) juga menguji apakah penurunan relevansi nilai disebabkan oleh perubahan teknologi yang diadopsi perusahaan. Pengujian dilakukan menggunakan perusahaan teknologi tinggi dan perusahaan non teknologi tinggi. Hasil pengujian mengindikasikan hal yang sama dengan pengujian menggunakan seluruh sampel yaitu perusahaan dengan teknologi tinggi tidak mengalami penurunan relavansi nilai dibandingkan dengan perusahaan non teknologi tinggi.

Teoh et al. (1998) menguji perilaku manajemen laba selama periode penawaran ekuitas perusahaan menggunakan sampel sebanyak 6836 dari tahun 1976-1989. Penelitiannya dibagi menjadi beberapa periode penelitian mulai dari $\mathrm{t}-3$ sampai dengan $\mathrm{t}+3$ untuk melihat pergerakan relevansi nilai. Hasil penelitiannya menemukan terjadinya manajemen laba melalui discretionary accrual yang meningkat sebelum periode penawaran, memuncak pada periode penawaran, dan menurun setelah periode penawaran. Penurunan net income yang terjadi setelah periode penawaran disebabkan karena perusahaan telah melakukan discretionary accrual yang agresif sebelum periode penawaran. Hasil penelitiannya juga menemukan hubungan negatif antara discretionary accrual sebelum dan sesudah penawaran ekuitas.

Lev dan Zarrowin (1999) melakukan pengujian kembali terhadap relevansi nilai informasi akuntansi dan menemukan terjadinya penurunan explanatory power dari informasi akuntansi, terutama earnings, aliran kas dan nilai buku selama dua puluh tahun. Penelitiannya menggunakan sampel sebanyak 1.300 perusahaan di file Compustat tahun 1978-1996 dan menggunakan variabel earnings, cash flow, dan book value untuk mengukur relevansi nilai $(E R C)^{2}$. Alasan dari penurunan nilai ini dikarenakan selama dua puluh tahun perkembangan pasar modal, terjadi perubahan dalam bisnis dan terjadi kenaikan beban research dan development yang direspon positif oleh investor.

Dontoh et al. (2004) yang menguji prediksi teoritis yang muncul dari rasional gangguan ekspektasi model keseimbangan menjelaskan telah terjadi penurunan temporal dalam asosiasi antara harga saham dan informasi akuntansi (laba dan nilai buku), yang kemungkinan terjadi akibat aktivitas perdagangan berbasis non-informasi (non-information based atau NIB). Penelitiannya membandingkan antara relevansi nilai berdasarkan informasi akuntansi dan relevansi nilai berdasarkan NIB. Relevansi nilai informasi akuntansi diukur menggunakan variabel net income (NI) dan book value (BV) dan relevansi nilai NIB diukur menggunakan residual yang diperoleh dari persamaan relevansi nilai informasi akuntansi. Sampel penelitian menggunakan data perusahaan di Compustat tahun 1983-2000. Hasilnya menemukan relevansi nilai berdasarkan net income dan book value

${ }^{2}$ Lev dan Zarrowin (1999) mengukur relevansi nilai menggunakan earning respon coefficient (ERC). 
mengalami penurunan, terlihat dari nilai $R^{2}$ regresi harga saham dalam informasi akuntansi yang menurun. Nilai $\mathrm{R}^{2}$ yang diperoleh dari persamaan regresi net income dan book value juga ditemukan berhubungan negatif dengan NIB, dan disimpulkan menurunnya relevansi nilai informasi akuntansi (net income dan book value) disebabkan oleh NIB.

Marquardt dan Wiedman (2004) menguji relevansi nilai berdasarkan pendekatan earnings dan nilai buku perusahaan yang melakukan manajemen laba. Menggunakan sampel sebanyak 192 yang dibagi menjadi sampel perusahaan yang sahamnya dimiliki oleh kelompok manajemen sebanyak 199 observasi dan sampel perusahaan yang sahamnya tidak dimiliki oleh kelompok manajemen sebanyak 73 observasi dengan total sampel sebanyak 192 observasi pada tahun 1984-1991. Periode penelitiannya dibagi menjadi beberapa perioda penelitian, yaitu $t-1, t_{0}, t_{+1}$, $t_{+2}$, dan $t_{+3}$ untuk melihat pola pergerakan relevansi nilai $\left(R^{2}\right)$ selama beberapa waktu setelah dilakukannya sasoned equity offering. Ditemukan bukti terjadi penurunan relevansi nilai pendekatan earnings perusahaan dan terjadi peningkatan relevansi nilai informasi atas nilai buku. Hasil pengujian menggunakan sampel perusahaan yang melakukan discretionary accrual dan non discertionary accrual juga memberikan kesimpulan sama, yaitu terjadi penurunan relevansi nilai setiap tahunnya. Hasil penelitiannya menyimpulkan pendekatan nilai buku berperan lebih penting menentukan relevansi nilai ketika perusahaan melakukan manajamen laba.

Berbeda dengan pendekatan di atas, dilihat dari fakta bahwa kegiatan di pasar tradisional cenderung konstan dan stabil. Hal ini juga dibuktikan melalui kemampuan bertahan dan bersain dalam masa krisis di Indonesia. Oleh karena itu penelitian ini mencoba untuk melihat antara relevansi pasar modal dan pasar rakyat dengan kerangka penelitian sebagai berikut:

\section{Kerangka Pemikiran}

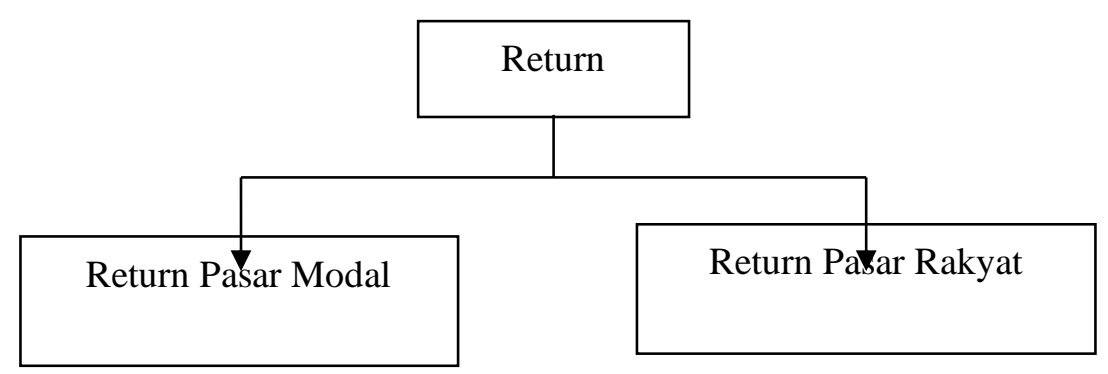

Gambar 1. Kerangka Pemikiran

\section{METODE PENELITIAN}




\section{DA}

Vol. 6, No. 1, Oktober 2021

Penelitian ini merupakan penelitian dengan menggunakan pendekatan kualitatif. Pendekatan kualitatif deskriftif dimaksudkan untuk menggambarkan fenomena yang terjadi di lapangan menggunakan data sekunder Bursa Efek Indonesia dan Pasar Rakyat. Penelitian dilakukan di Pasar Modal Bursa Efek Indonesia dan Pasar Rakyat di Kota Mataram, dengan alasan investor memiliki konsep untuk menghasilkan return atau pengembalian semaksimal mungkin dengan resiko yang rendah. Investasi yang dilakukan dapat di berbagai bidang dan di mana saja, seperti Pasar modal, pasar komoditi, pasar rakyat, valas. Penggalian data di lapangan peneliti lakukan dengan cara teknik analisis data sekunder di pasar modal dan pasar rakyat dengan menggunakan sampel acak per harian transaksi penjualan untuk memperoleh return harian.

\section{HASIL PENELITIAN DAN PEMBAHASAN}

Sebelum menjelasakan hasil temuan data di lapangan menggunakan data sekunder responden di pasar rakyat atau pasar tradisional dengan pasar saham Bursa Efek Indonesia, ada baiknya dijelaskan secara singkat mengenai deskripsi hasil penggalian data di lapangan.

Tabel 1. Deskripsi Sampel dan Responden Penelitian

\begin{tabular}{|c|c|c|c|c|c|c|}
\hline No & Tanggal & Kode & Nama & Return & Nama & Return \\
\hline 1 & 17 NOv 2020 & Pasar Cakra & Barang Antik & $200 \%$ & Ace Hardware Indonesia Tbk & $0.30 \%$ \\
\hline 2 & 17 NOv 2020 & $\begin{array}{l}\text { Pasar Kebon } \\
\text { Roek }\end{array}$ & Ikan & $30 \%$ & Sumber Alfaria Trijaya Tbk & $-1.37 \%$ \\
\hline 3 & 17 NOv 2020 & $\begin{array}{l}\text { Pasar Kebon } \\
\text { Roek }\end{array}$ & Daging & $17 \%$ & Catur Sentosa Adiprana Tbk & $-1.85 \%$ \\
\hline 4 & 17 NOv 2020 & $\begin{array}{l}\text { Pasar Kebon } \\
\text { Roek }\end{array}$ & Buah & $17 \%$ & Duta Intidaya Tbk & $0.00 \%$ \\
\hline 5 & 17 NOv 2020 & $\begin{array}{l}\text { Pasar Kebon } \\
\text { Roek }\end{array}$ & Sayur & $10 \%$ & $\begin{array}{l}\text { Distribusi Voucher Nusantara } \\
\text { Tbk }\end{array}$ & $-3.26 \%$ \\
\hline 6 & 17 NOv 2020 & $\begin{array}{l}\text { Pasar Kebon } \\
\text { Roek }\end{array}$ & Pepaya & $30 \%$ & Electronic City Indonesia Tbk & $0.00 \%$ \\
\hline 7 & 17 NOv 2020 & $\begin{array}{l}\text { Pasar Kebon } \\
\text { Roek }\end{array}$ & Beras & $44 \%$ & Erajaya Swasembada Tbk & $-0.54 \%$ \\
\hline 8 & 17 NOv 2020 & $\begin{array}{l}\text { Pasar Kebon } \\
\text { Roek }\end{array}$ & Jajan & $30 \%$ & Global Teleshop Tbk & $0.00 \%$ \\
\hline 9 & 17 NOv 2020 & $\begin{array}{l}\text { Pasar Kebon } \\
\text { Roek }\end{array}$ & Pelastik & $9 \%$ & Hero Supermarket Tbk & $-1.23 \%$ \\
\hline 10 & 17 NOv 2020 & $\begin{array}{l}\text { Pasar Kebon } \\
\text { Roek }\end{array}$ & Kopi & $12 \%$ & Kioson Komersial Indonesia Tbk & $0.00 \%$ \\
\hline 11 & 17 NOv 2020 & $\begin{array}{l}\text { Pasar Kebon } \\
\text { Roek }\end{array}$ & Bumbu & $10 \%$ & Kokoh Inti Arebama Tbk & $0.00 \%$ \\
\hline 12 & 17 NOv 2020 & $\begin{array}{l}\text { Pasar Kebon } \\
\text { Roek }\end{array}$ & Gula & $13 \%$ & Matahari Department Store Tbk & $13 \%$ \\
\hline 13 & 17 NOv 2020 & $\begin{array}{l}\text { Pasar Kebon } \\
\text { Roek }\end{array}$ & Garam & $15 \%$ & Mitra Adiperkasa Tbk & $0.00 \%$ \\
\hline 14 & 17 NOv 2020 & $\begin{array}{l}\text { Pasar Kebon } \\
\text { Roek }\end{array}$ & Panci & $7 \%$ & M Cash Integrasi Tbk & $-4.19 \%$ \\
\hline 15 & 17 NOv 2020 & $\begin{array}{l}\text { Pasar Kebon } \\
\text { Roek }\end{array}$ & Pisang & $24 \%$ & Midi Utama Indonesia Tbk & $0.00 \%$ \\
\hline
\end{tabular}




\begin{tabular}{|c|c|c|c|c|c|c|}
\hline 16 & 17 NOv 2020 & $\begin{array}{l}\text { Pasar Kebon } \\
\text { Roek }\end{array}$ & Nangka & $9 \%$ & Mitra Komunikasi Nusantara Tbk & $0.00 \%$ \\
\hline 17 & 17 NOv 2020 & $\begin{array}{l}\text { Pasar Kebon } \\
\text { Roek }\end{array}$ & Alat Masak & $13 \%$ & Matahari Putra Prima Tbk & $0.00 \%$ \\
\hline 18 & 17 NOv 2020 & $\begin{array}{l}\text { Pasar Kebon } \\
\text { Roek }\end{array}$ & Periuk & $12 \%$ & NFC Indonesia Tbk & $0.00 \%$ \\
\hline 19 & 17 NOv 2020 & $\begin{array}{l}\text { Pasar Kebon } \\
\text { Roek }\end{array}$ & Ember & $9 \%$ & Ramayana Lestari Sentosa Tbk & $4.35 \%$ \\
\hline 20 & 17 NOv 2020 & $\begin{array}{l}\text { Pasar Kebon } \\
\text { Roek }\end{array}$ & Baju Anak & $18 \%$ & Supra Boga Lestari Tbk & $-0.50 \%$ \\
\hline 21 & 17 NOv 2020 & $\begin{array}{l}\text { Pasar Kebon } \\
\text { Roek }\end{array}$ & Perhiasan & $20 \%$ & Rimo International Lestari Tbk & - \\
\hline 22 & 17 NOv 2020 & $\begin{array}{l}\text { Pasar Kebon } \\
\text { Roek }\end{array}$ & Mainan Anak & $30 \%$ & Skybee Tbk & - \\
\hline 23 & 17 NOv 2020 & $\begin{array}{l}\text { Pasar Kebon } \\
\text { Roek }\end{array}$ & $\begin{array}{l}\text { Akesoris } \\
\text { Perhiasan }\end{array}$ & $25 \%$ & $\begin{array}{l}\text { Sona Topas Tourism Industry } \\
\text { Tbk }\end{array}$ & $0.00 \%$ \\
\hline 24 & 17 NOv 2020 & $\begin{array}{l}\text { Pasar Kebon } \\
\text { Roek }\end{array}$ & Anyaman Bambu & $12 \%$ & Tiphone Mobile Indonesia Tbk & - \\
\hline 25 & 17 NOv 2020 & $\begin{array}{l}\text { Pasar Kebon } \\
\text { Roek }\end{array}$ & Bumbu Masak & $10 \%$ & Trikomsel Oke Tbk & - \\
\hline \multicolumn{4}{|c|}{ Return Harian Rata-Rata } & $25.04 \%$ & Return Harian Rata-Rata & $0.20 \%$ \\
\hline
\end{tabular}

Tabel 1. menjelaskan return dari hasil penjualan yang dilakukan di dua pasar, yaitu pasar Bursa Efek Indonesia dan Pasar Tradisonal di daerah Mataram. Adapun data yang digunakan melalui pemilihan entitas atau perusahaan yang bergerak di bidang retail di Bursa Efek Indonesia dan Retail di Pasar Tradisional.

Data penelitian yang telah disajikan pada tabel di atas menujukkan perbedaan antara return harian bursa efek dan return pasar tradisional. Secara lebih detail dapat dijelasakan bahwa terdapat perbedaan yang cukup besar antara return harian di pasar modal dengan di pasar tradisional. Rata rata return harian di pasar modal sebesar $0.20 \%$ dibandingkan dengan Pasar Tradisional sebesar $25 \%$.

Perbedaan ini secara logika sangat mencolok dan menarik untuk dikaji lebih mendalam bahwa keberadaan pasar tradisional tetap eksis selama masa pandemi atau di masa krisis moneter tahun tahun lalu. Sehingga banyak yang menyatakan bahwa keberadaan Usaha Kecil Menengah (UMKM) atau pasar tradisional banyak membantu perekonomian.

Hasil penelitian ini mendukung pernyataan teori yang menjelaskan kegiatan di pasar tradisional cenderung konstan dan stabil. Hal ini juga dibuktikan melalui kemampuan bertahan dan bersain dalam masa krisis di indonesia. Bagian ini memuat hasil analisis data, pengujian hipotesis, menjawab pertanyaan-pertanyaan penelitian, temuan-temuan dan menginterpretasikan temuan-temuan.

\section{SIMPULAN}

Penelitian ini menguji perbedaan relevansi nilai pasar saham dan pasar rakyat untuk memperoleh bukti empiris tentang relevansi nilai return saham antara pasar modal dan pasar rakyat. Penelitian ini dilakukan di 


\section{$J A A$}

Vol. 6, No. 1, Oktober 2021

sekitar ruang lingkup Pasar Modal Indonesia dan Pasar Tradisional di daerah Mataram. Terdapat beberapa manfaat dari hasil penelitian ini, yaitu secara teoritis, praktis, dan kebijakan. Hasil penelitian menunjukkan nilai Return Pasar rakyat lebih menguntungkan dibandingkan dengan Pasar Modal.

Implikasi teoritis untuk dasar menilai return pasar modal dan pasar saham, bahwa pasar rakyat atau Usaha Kecil Menengah (UMKM) memiliki nilai return yang positif di Indonesia. Implikasi praktis penelitian ini digunakan sebagai pertimbangan manajemen berinvestasi investor, bahwa investasi lokal lebih menguntungkan dibandingkan dengan investasi saham di pasar modal dengan asumsi modal yang tidak banyak. Implikasi kebijakan diharapkan dari penelitian ini yaitu dapat digunakan sebagai pertimbangan bagai pemerintah dan lembaga berwenang untuk lebih memajukan UMKM di Indonesia.

\section{DAFTAR PUSTAKA}

Ball, R. and P. Brown.1968. An Empirical Evaluation of Accounting Income Numbers. Journal of Accounting Research. Vol. 6 (Autumn). pp. 159178

Barth, M.E., and WR Landsman. 1995. Fundamental Issues Related to Using Fair Value Accounting for Financial Reporting. Accounting Horizon. Vol. 9 No. 4. pp. 97-107.

Barth, ME., John A. Elliot, and Mark W. Finn. 1999. Market Rewards Associated With pattern on Increasing Earning. Journal of Accounting Research. Vol. 2 (Autumn). pp. 387-413.

Barth, ME., W.H. Beaver and W.R. Landsman. 2001. The Relevance of Value Relevance Research for Financial Accounting Standard Setting: Another View. Journal of Accounting and Economics. Vol. 39 (September). pp. 77-104.

Beaver, William H. 1968. The Information Content of Earnings. Journal of Accounting Research. Vol. 6 (supplement) pp. 67-92.

Beaver, William H. 2002. Perspectives on Recent Capital Market Research. The Accounting Review. Vol 7 (2) April. pp. 453-474.

Brown, Stephen., Kin Lo and Thomas Lys. 1999. Use of $\mathrm{R}^{2}$ in Accounting Research: Measuring Changes in Value Relevance Over the Last Four Decades. Journal of Accounting and Economics. Vol. 28. pp. 83-115.

Burgstahler, D. and I. Dichev, 1997, Earning, Adaption, and Equity Value, The Accounting Review, vol 72 pp187-215.

Dechow, P, R. Sloan and Sweeney, 1995. Detecting Earning Management. The Accounting Review. Vol 70 pp.193-226.

Dontoh, Alex., Suresh Radhakrishnan and Joshua Ronen. 2004. The Declining Value Relevance of Accounting Information and Non- 
Information-Based Trading: An Empirical Analysis. Contemporary Accounting Research. Vol. 21 pp. 793-812.

Francis, Jennifer and Catherine Schipper. 1999. Have Financial Statements Lost Their Relevance. Journal of Accounting Research. Vol. 37 (2). pp. 319-352.

Healy, P., 1985. The The Impact of Bonus Scheme on Selection of Accounting Principles. Journal of Accounting and Economic.

Healy, P. And J.M. Wahlen. 1999. A Review of Earning Managements Literature and Its Implication for Standart Setting. Accounting Horizon Vol 13 pp.365-384.

Jones, Jeniffer J. 1991. Earnings Management During Import Relief Investigation. Journal of Accounting Research, Vol 29 No 2 Autumn.

Lev, Baruch and Paul Zarowin. 1999. The Boundaries of Financial Reporting and How To Extend Them. Journal of Accounting Research. Vol. 37 (2). pp. 353-385.

Marquardt, Carol A. dan Christine I. Weidman, 2004. The Effect Of Earnings Management On Value Relevance Of Accounting Information. Journal of Business Finance and Accounting.

Ohlson, James A. 1995. Earnings, Book Values, and Dividen in Equity Valuation. Contemporary Accounting Research, Vol 11 No 2 Spring.

Peraturan Menteri Perdagangan RI Nomor: 56/M_DAG/PER/9/2014 tentang Perubahan atas Peraturan Menteri Perdagangan Nomor 70/M-DAG/PER/12/2013 Tentang Pedomanan Penataan dan Pembinaan Pasar Tradisional, Pusat Perbelanjaan dan Toko Modern

Sloan, R., 1996. Do Stock Price fully Reflect Information in Accruals and Cash Flow About Future Earnings? The Accounting Review.

Subramanyam, K. R., 1996. The Pricing of Discretionary Accrual. Journal of Accounting and Economic. Vol 22 pp. 249-281.

Teoh Siew Hong, Ivo Welch, and T.J. Wong. 1998. Earning Management and the Underperformance of Seasoned Equity Offering. Journal of Financial Economic. Vol 50 pp.63-99.

UU No. 8 Tahun 1995 